\title{
Preliminary results from the implementation of the SPUR2 model in Uruguay
}

\author{
Juan Pablo Chiara*, Gabriela Cruz \\ Cátedra de Agrometeorología, Facultad de Agronomía, Universidad de la República, Avda. Garzón 780, \\ Montevideo, Uruguay
}

\begin{abstract}
Results from the first attempt at implementing the SPUR2 (Simulation of Production and Utilization of Rangelands) simulation model under the specific conditions of a deep soil on basalt rock in Uruguay are presented. The study area was selected because it represents a large portion of Uruguayan land ( $21 \%$ ) almost exclusively oriented to cattle production; due to the variety of soil types in this region it was possible to analyze contrasting situations regarding vulnerability to the occurrence of extreme climatic events-- such as droughts - and to potential climate changes. The information used, which included soil texture, organic matter content and hydrologic characteristics, corresponded to a representative soil of the Itapebí Tres Arboles unit. The weather data used were daily records for precipitation, as well as air temperature, solar radiation and wind run data simulated with a climate generator program. The model was run for the 1961-1990 period under normal (present day) carbon dioxide concentration conditions. The analysis focussed particularly on the SPUR2 outputs of the hydrology and plant submodels. Biomass production simulations showed a good representation of reality with regard to annual production. However, they differed from the actual data available for this area with regard to the seasonal distribution of forage. The results of the hydrology submodel significantly departed from the expected values. Potential evapotranspiration reached monthly values $148 \%$ above normal (observed), which could be partly explained by the fact that the global solar radiation estimates were higher than the real values.
\end{abstract}

KEY WORDS: Simulation model · SPUR2 - Natural pastures · Grazing system · Climate change

\section{INTRODUCTION}

Uruguay is located in South America, between $30^{\circ}$ and $35^{\circ} \mathrm{S}$. It covers an area of approximately $176000 \mathrm{~km}^{2}$.

The mean annual temperature is $17.8^{\circ} \mathrm{C}$. During the cold season (winter) frost is common. However, low temperatures are not an impediment to the growth of pastures. The mean minimum temperature in the coldest month (July) is $7^{\circ} \mathrm{C}$. The frost-free period is approximately $300 \mathrm{~d}$ long. The mean maximum temperature in the warmest month (January) is $31^{\circ} \mathrm{C}$. Mean annual precipitation is estimated at $1274 \mathrm{~mm}$. Even though precipitation is well distributed over the year, it is characterized by considerable interannual variation. The annual distribution of the potential evapotranspiration

•E-mail: jp@agrome.edu.uy shows a considerable seasonality, with a maximum of $214 \mathrm{~mm}$ in January and a minimum of $33 \mathrm{~mm}$ in June (Boshell \& Chiara 1982).

The agricultural sector in Uruguay, particularly the extensive beef livestock production on grasslands, is one of the traditional pillars of the country's economy.

The basalt region is an important area for cattle production supported on natural pastures. Different soils in this region have contrasting characteristics with regard to water-holding capacity and type of pasture. This allows for the analysis of clearly different situations with respect to vulnerability to the occurrence of extreme events within a climatically homogeneous area

A simulation model designed for grassland/livestock ecosystems, adequately calibrated and validated for the country's conditions, represents a valuable tool which can be applied, for instance, in farm manage- 
ment, research or policy development. It is particularly useful for analyzing and understanding the occurrence of extreme climatic events, such as droughts, and for evaluating the potential effects of climate change on the productive sector.

SPUR2 (Simulation of Production and Utilization of Rangelands) (U.S. Country Studies Program 1994) is an improved version of the SPUR model (Wight \& Skiles 1987). The model is made up of submodels which simulate different processes with regard to plants, the soil, the different classes of animals which compete for forage and the effects of grazing. It is driven by daily weather data and can simulate up to 15 plant species in up to 36 sites at the same time.

The goal of this study was to evaluate the behaviour of the SPUR2 model under the conditions of the Uruguayan deep basalt region. The study was carried out within the framework of the vulnerability and adaptation assessment of the Uruguay Climate Change Country Study coordinated by the 'Comision Nacional sobre el Cambio Global'.

\section{METHODS}

2.1. Study area. The area selected for this study was the basalt region, which is located in the north of Uruguay, more precisely to the north of the Río Negro, and is best represented in the Department of Salto. This area is characterized by the predominance of cattle production on natural grasslands.

2.2. Information used. Weather data: The daily weather data used were derived using CLIMGEN (Wight \& Skiles 1987). This program generates weather data using monthly temperature and daily precipitation data.

A data file for the period 1961 to 1990 was created and contained daily maximum and minimum air temperatures, precipitation, global solar radiation, and wind run values from the Salto weather station (M. Bidegain pers. comm.).

Given that SPUR2 was not designed to be used in the Southern Hemisphere, it was necessary to modify the correspondence between the dates and the data. For this purpose, January 1 was replaced by July 1 (beginning of the agricultural year in Uruguay) and so on.

Soils: The soil used in this study corresponds to Unit 4 (Itapebí Tres Arboles) of the 'Carta de Reconocimiento de Suelos del Uruguay' (scale 1:1000000), developed on basalt rock (J. Molfino pers. comm.)

A clayey 'Vertisol Háplico' soil-UYM13-01 profile (Typic Peludert) - was selected as representative of the deep soils of the region. This is mainly a grazing soil, with high natural fertility and which is moderately well drained.
Vegetation: Individual plant species as well as functional groups can be included in the simulation process. A functional group is a group of plant species that respond in a physiologically uniform manner to biotic and abiotic factors in the environment (U.S. Country Studies Program 1994). In SPUR2, groupings are made on the basis of photosynthetic pathway and physical structure (plant architecture).

A survey was carried out to obtain the input data required to run and validate the model. Data were collected from different sources, namely the Instituto Nacional de Investigación Agropecuaria (INIA), the Facultad de Agronomía of the Universidad de la República, and the Ministerio de Ganadería, Agricultura y Pesca (MGAP).

The following functional groups were considered, based on the information compiled: warm-season grasses, cool-season grasses, warm-season forbs and cool-season forbs. The following phenological data were also included: dates for beginning and ending of senescence, and dates for beginning of seed production (Rosengurtt 1979).

2.3. Calibration. Appropriate parameter sets for each submodel were developed for the calibration process. In this case, calibration and parameterization are considered as equivalent. Porosity, volumetric water content at $-1 / 3$ bar and -15 bar, and saturated-soil hydraulic conductivity were estimated from soil characteristics (Table 1) according to the procedure described by the U.S. Country Studies Program (1994).

The plant submodel included 43 parameters. National values for these parameters are scarcely available. However, some information was found regarding plant phenology (Table 2).

Table 1. UYM13-01 soil profile. OM: organic matter

\begin{tabular}{|lccccc|}
\hline Horizon & $\begin{array}{c}\text { Depth } \\
(\mathrm{cm})\end{array}$ & $\begin{array}{c}\text { Sand } \\
(\%)\end{array}$ & $\begin{array}{c}\text { Silt } \\
(\%)\end{array}$ & $\begin{array}{c}\text { Clay } \\
(\%)\end{array}$ & $\begin{array}{c}\text { OM } \\
(\%)\end{array}$ \\
\cline { 2 - 5 } Au1 & 20 & 7 & 37 & 56 & 8.7 \\
Au2 & 15 & 7 & 25 & 68 & 3.9 \\
Au3 & 34 & 9 & 22 & 69 & 2.6 \\
C & 11 & 11 & 24 & 65 & 2.0 \\
2Ck & 5 & 54 & 18 & 28 & 0.5 \\
\hline
\end{tabular}

Table 2. Phenological parameters of the plant submodel

\begin{tabular}{|lcc|}
\hline & \multicolumn{2}{c|}{$\begin{array}{c}\text { Dates (days from Jan 1) } \\
\text { Warm season }\end{array}$} \\
& & Cool season \\
\hline Beginning of seed production & 304 & 261 \\
Beginning of senescence & 319 & 265 \\
Ending of senescence & 146 & 295 \\
\hline
\end{tabular}


The set of initial conditions for soil inorganic $\mathrm{N}$, dead roots, litter, soil organic matter, live roots, propagules, standing live biomass and standing dead biomass, were estimated by running the model for $30 \mathrm{yr}$ (with the initial default values). The ending values for these parameters were used as initial values (Tables $3 \& 4$ ).

An interactive calibration was carried out to adjust the parameters corresponding to the proportion of organic matter susceptible to decomposition (0.0035), proportion of root respiration, proportion of root mortality and root-to-shoot ratio (Table 5). An acceptable stability was achieved for 10 -year periods in the successive model runs with regard to soil organic matter, live root biomass, litter and dead root biomass outputs. Further, the outputs corresponding to the annual peak for standing biomass and functional group biomass

Table 3. Initial carbon parameters $\left(\mathrm{g} \mathrm{m}^{-2}\right)$

\begin{tabular}{|lrrrrr|}
\hline \multirow{2}{*}{ Parameter } & \multicolumn{2}{c}{ Grasses } & \multicolumn{2}{c|}{ Forbs } \\
& Season: & Warm & Cool & Warm & Cool \\
\hline Standing green biomass & 8.929 & 1.784 & 0.000 & 1.370 \\
Live root biomass & 901.697 & 141.515 & 0.001 & 12.625 \\
Propagule biomass & 0.260 & 0.315 & 0.000 & 0.190 \\
Standing dead biomass & 54.646 & 2.628 & 0.000 & 0.520 \\
& & & & \\
\hline
\end{tabular}

Table 4. Initial nitrogen parameters $\left(\mathrm{g} \mathrm{m}^{-2}\right)$

\begin{tabular}{lr}
\cline { 2 - 2 } Parameter & \\
\hline Soil inorganic N & 6.59 \\
Dead roots & 178.75 \\
Litter & 211.43 \\
Soil organic matter & 3137.68 \\
\hline
\end{tabular}

Table 5. Root distribution parameters adjusted in the calibration process. Prop.: proportion of

\begin{tabular}{|llllll|}
\hline \multirow{2}{*}{ Parameter } & \multicolumn{2}{c}{ Grasses } & \multicolumn{2}{c|}{ Forbs } \\
& \multicolumn{1}{c}{ Season: } & Warm & \multicolumn{1}{c|}{ Cool } & \multirow{2}{*}{ Warm } & Cool \\
\hline Root/shoot ratio & 6.8 & 8.0 & & 4.0 & 4.0 \\
Prop. root respiration & 0.00043 & 0.0032 & 0.001 & 0.0011 \\
Prop. root mortality & 0.00089 & 0.0029 & 0.002 & 0.0024 \\
\hline
\end{tabular}

Table 6 . Contribution (\%) of the different forage system components in the deep basalt region (Carámbula 1991)

\begin{tabular}{|c|c|c|c|c|c|}
\hline \multicolumn{2}{|c|}{ Grasses } & \multirow[t]{2}{*}{ Legumes } & \multirow[t]{2}{*}{ Weeds } & \multirow[t]{2}{*}{ Litter } & \multirow{2}{*}{$\begin{array}{c}\text { Bare } \\
\text { soil }\end{array}$} \\
\hline $\begin{array}{l}\text { Warm } \\
\text { season }\end{array}$ & $\begin{array}{c}\text { Cool } \\
\text { season }\end{array}$ & & & & \\
\hline 49.5 & 12.8 & 3.8 & 5.8 & 15.1 & 13.0 \\
\hline
\end{tabular}

were compared with the mean production values available for the area. Annual forage production in the deep basalt region has been estimated to be 4077,3800 and $3900 \mathrm{~kg} \mathrm{ha}{ }^{-1}$ by Carámbula (1991), Crempien (1983) and De Souza (1985), respectively. The contribution $(\%)$ of the different forage system components in the region is shown in Table 6.

SPUR2 default values were used when data were not available for the determination of the parameters required.

2.4. Validation. The model validation process consists of assessing the extent to which the model replicates real observations. In this case the validation consisted in comparing some outputs of the plant submodel (PLNTOUT.SDF and PEAKPLT.SDF files) and of the hydrology submodel (SUMARY.SDF) with the data available in the literature.

The 1984 to 1987 period was selected out of the period for which SPUR2 dry matter outputs were obtained (1961 to 1990). Fifteen-day averages were calculated. This procedure was performed to obtain values which could be compared with the observed data available for the region during the same time frame. SPUR2 outputs of annual production peak (dry matter value equivalent to total annual production) for the period 1984 to 1987 were also averaged in order to compare them with the experimental values of total annual production for the same period. The total annual production values for the agricultural years 1984-1985 and 1986-1987 were also compared.

Model estimates of potential evapotranspiration (PET) were averaged on a monthly basis for the 1961 to 1990 period and compared with the normal (calculated with 30 yr averages) values (Boshell \& Chiara 1982).

With regard to available soil water (AW), it was considered more appropriate to group model output into different classes and determine the frequency of each class (see Fig. 1) The most representative classes were selected. Intervals of $30 \mathrm{~mm}$ were defined for AW values $>0$ and $\leq 120 \mathrm{~mm}$. Classes were also defined for values $>120 \mathrm{~mm}$ and for values equal to 0 . The results corresponding to the AW at the end of the month were compared with the available information (published and unpublished).

\section{RESULTS}

\subsection{Potential evapotranspiration}

The mean model PET estimate was $1851 \mathrm{~mm}$ per year. The mean PET values on a seasonal and monthly basis are shown in Table 7 . The minimum monthly PET value of $82 \mathrm{~mm}$ was found in June and the maximum of $235 \mathrm{~mm}$ in January. 
Table 7. SPUR2 PET monthly and seasonal averages (mm) for the Department of Salto

\begin{tabular}{|c|c|c|c|c|c|c|c|}
\hline \multicolumn{2}{|c|}{ Fall } & \multicolumn{2}{|c|}{ Winter } & \multicolumn{2}{|c|}{ Spring } & \multicolumn{2}{|c|}{ Summer } \\
\hline Mar & 166 & Jun & 82 & Sep & 138 & Dec & 225 \\
\hline Apr & 129 & Jul & 85 & Oct & 172 & Jan & 235 \\
\hline May & 95 & Aug & 95 & Nov & 217 & Feb & 212 \\
\hline Total & 390 & & 262 & & 527 & & 672 \\
\hline
\end{tabular}

\subsection{Available soil water}

The frequencies of the available soil water for each class are shown in Fig. 1. The highest frequency of the $\mathrm{AW}=0$ class $(47 \%)$ occurs in December. The frequencies of this class progressively decrease in the subsequent months, reaching a zero value in June and July.
On the other hand, the AW > 120 mm class, which corresponds to AW close to the water holding capacity (AW higher than $80 \%$ ), reaches a $3 \%$ frequency in June and August, while in the remaining months the frequency is zero.

\subsection{Forage production}

The evolution by 15-day periods of the biomass of the different functional plant groups from 1961 to 1990 is shown in Fig. 2. A clear predominance of warmseason species over cool-season species is observed.

The total annual production of dry matter for the different periods is presented in Table 8 . The seasonal dry matter production, according to model outputs (Fig. 3), reaches a maximum in the spring and a minimum in the fall.
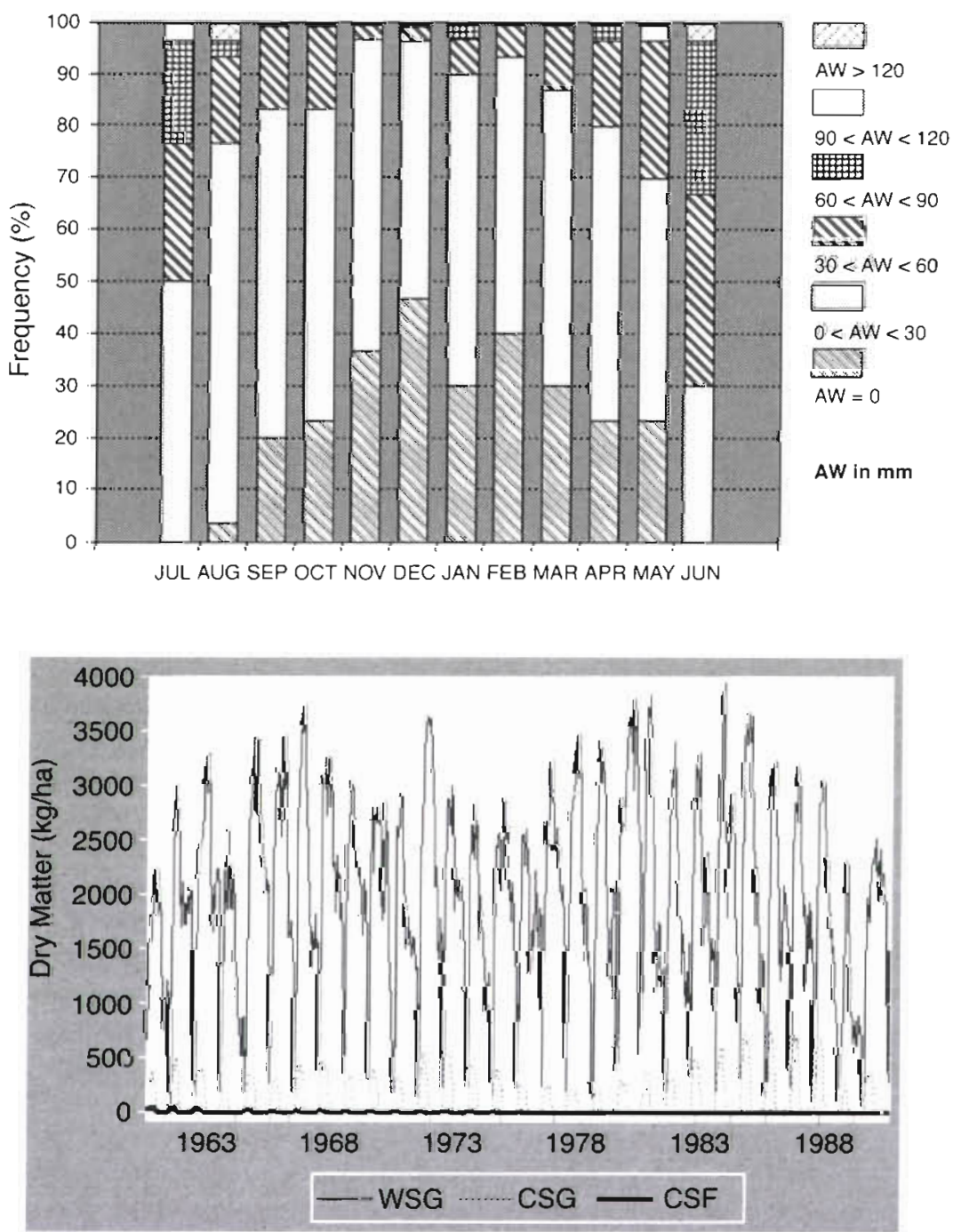

Fig. 1 SPUR2 outputs of available soil water frequencies, Salto
Fig. 2. Biomass evolution (SPUR2), deep basalt region, 1961 to 1990. WSG: warmseason grasses; CSG: cool-season grasses: CSF: cool-season forbs 
Table 8. Mean annual and total annual production of dry matter $\left(\mathrm{kg} \mathrm{ha}^{-1}\right)$

\begin{tabular}{|llc|}
\hline Period & \multicolumn{1}{c|}{ Observed prod. } & Simulated prod. \\
\hline 1984-1987 & 4748 (Berretta 1994) & 4310 \\
Agric. year 1984-85 & 4417 (Meirelles \& Riani 1988) & 4620 \\
Agric. year 1986-87 & 3978 (Zunino \& Baptista 1988) & 4040 \\
\hline
\end{tabular}

30 years studied $(47 \%)$, which is not consistent with reality. On the other hand, high values of available soil water $(A W>120 \mathrm{~mm})$ during winter were simulated by the model with a lower frequency than their actual occurrence. Values of $\mathrm{AW}>120 \mathrm{~mm}$ were simulated during June and August only in 1 out of 30 years, which

\section{DISCUSSION}

As shown in Table 8, SPUR2 estimates of total annual dry matter production are consistent with the observed values, both regarding 4 -year averages and specific annual values. However, the model did not correctly reproduce the seasonal distribution curve (Fig. 3). Although the spring maximum production peak was simulated, the seasonal minimum occurring during the winter was not appropriately estimated.

The model overestimates summer and winter production and underestimates fall and spring production. According to model outputs, the seasonal minimum occurs in fall, with a gradual increase in production towards winter. This is the result of a sharp production increment systematically simulated after mid-June, which results in a higher winter production (Fig. 4). The increment actually observed is less abrupt and occurs at the end of August or the beginning of September. The same results were obtained even when the phenological dates were changed within the range mentioned by Rosengurtt (1979).

With regard to interannual variation of seasonal production, Berretta (1994) indicates that the highest values of the coefficient of variation correspond to winter and summer (35 and $38 \%$ respectively) while the lowest values correspond to fall (5\%). SPUR2 outputs for the same period were analyzed, resulting in the highest coefficient of variation for winter $(28 \%)$ and the lowest for spring (12\%), with intermediate values for fall and summer ( 20 and $21 \%$ respectively).

The mean monthly PET simulated with the hydrology submodel for the 1961 to 1990 period was compared with the normal values (Boshell \& Chiara 1982). As shown in Fig. 5, although the pattern of annual distribution is similar, a difference of 21 to $56 \mathrm{~mm}$ is found throughout the year. For this reason the PET simulated by the model is considerably higher than the real values. This difference is more significant for the winter months: in June and July the simulated PET is almost $2 \frac{1}{2}$ times the real climate values.

Available soil water results also behaved differently than expected. As shown in Fig. 1, months with available soil water lower than $50 \%(\mathrm{AW}<60 \mathrm{~mm})$ were clearly predominant. In December, the available soil water at the end of the month was zero in 14 out the would imply that water excess is unusual during these months. This is inconsistent with the fact that water excess is actually so common in the winter that it becomes an important limiting factor for soil tillage (Gonnet 1981). Generally, the available soil water estimates depart from the real values, showing a higher occurrence of dry months and a lower occurrence of wet months. This is related to the fact that PET affects the available soil water.

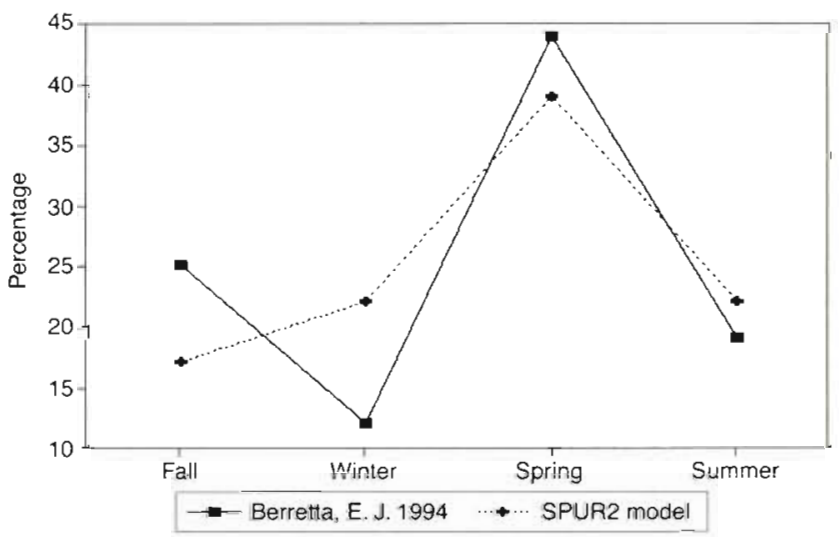

Fig. 3, Seasonal distribution of forage production, deep basalt region, 1984 to 1987

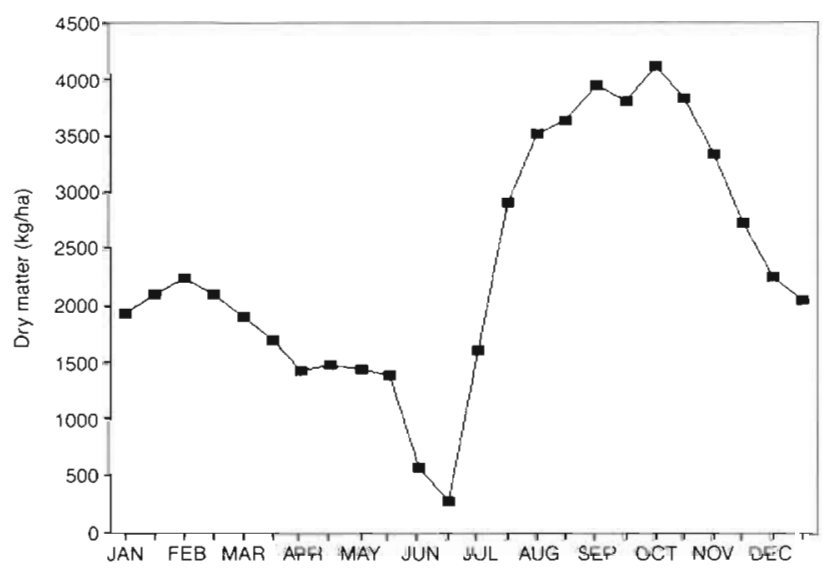

Fig. 4. Annual evolution of forage production (SPUR2), deep basalt region, 1984 to 1987 


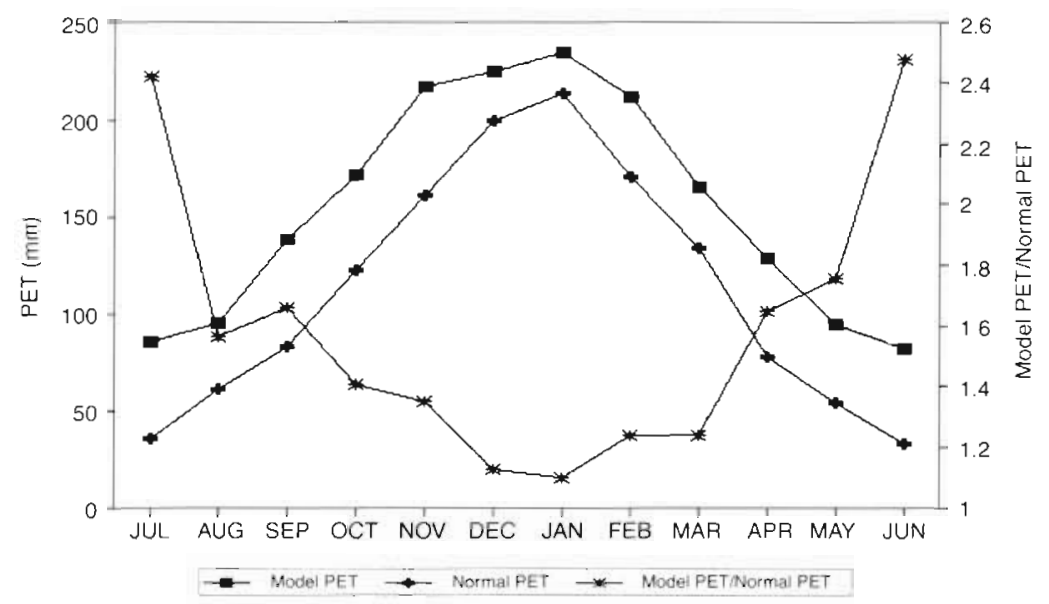

Fig. 5. Analysis of mean monthly PET, Salto

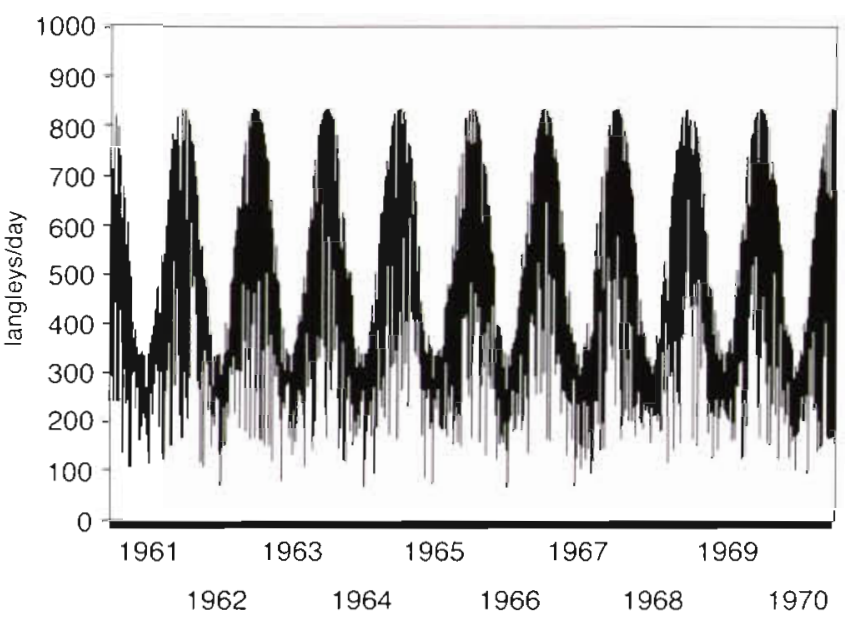

Fig. 6. Global solar radiation (SPUR2), Salto, 1961 to 1970

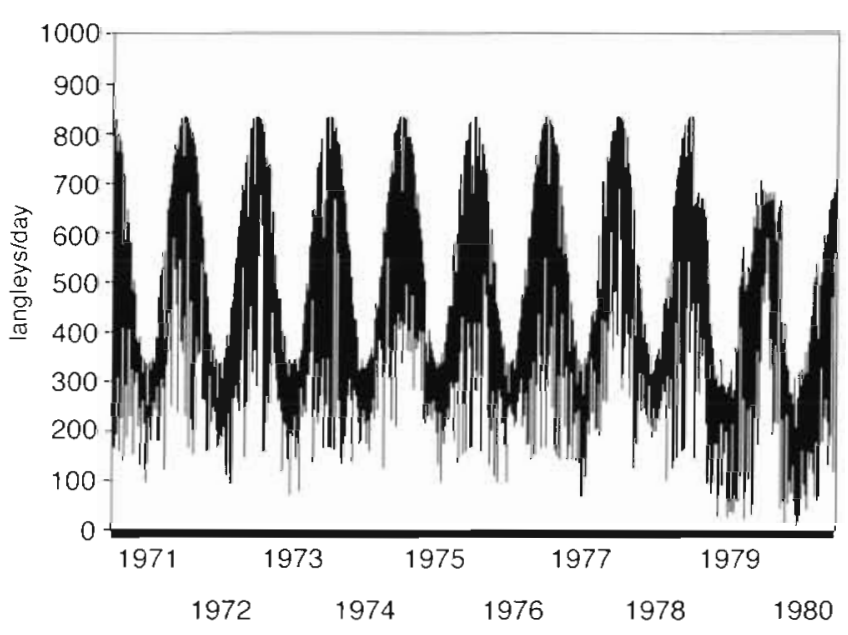

Fig. 7. Global solar radiation (SPUR2), Salto, 1971 to 1980
The possible causes for the simulated PET values being higher than real PET were assessed. It was observed that the CLIMGEN-generated global solar radiation values were higher than the real data available for the period 1979 to 1982 (Figs. 6 to 8). The average total annual values of global solar radiation for the periods assessed using the climate generator (19611978 and $1983-1991$ ) resulted in $163.2 \mathrm{kly}$, which is $20 \%$ higher than the average of observed values for the period 1979 to 1982 (135.43 kly).

\section{CONCLUSIONS}

SPUR2 provides estimates of dry matter total annual production for soils on deep basalt which are consistent with the observed values

The model displayed stability in the proportion of species throughout the years, with an acceptable estimate of warm-season and cool-season species.

Although the model is sensitive to seasonal changes, it did not appropriately simulate the seasonal distribution of forage for soils on deep basalt.

The intra-annual evolution of the evapotranspiration and the available soil water values was fairly close to the real curve. However, considerable differences in magnitude were found between the model outputs and the expected values.

The uncertainties in the global solar radiation data estimated by means of the CLIMGEN generator are clear evidence of the need to have daily weather records available for the analyses.

Although a good representation of reality can be obtained with SPUR2 with respect to forage production, a better performance of the hydrology submodel and a better simulation of the seasonal forage distribution need to be achieved before application of the 


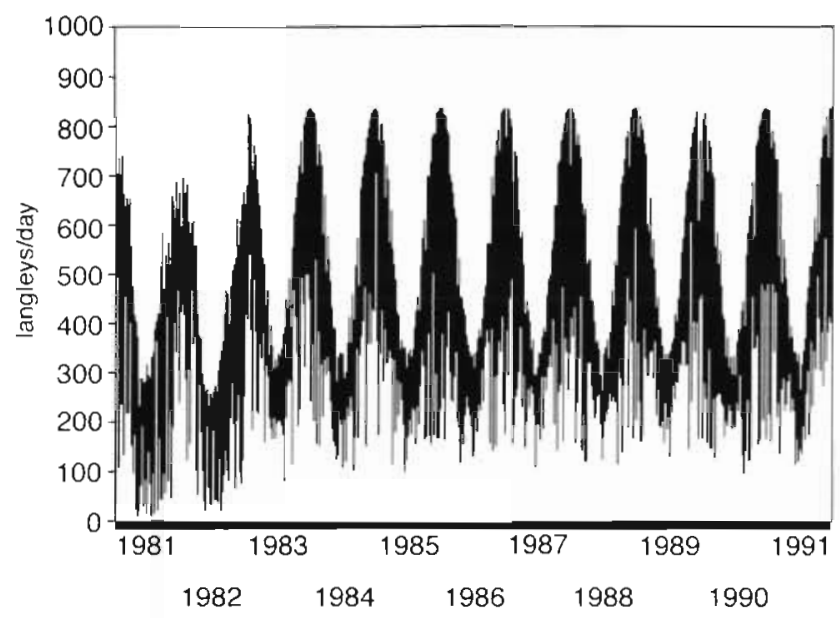

Fig. 8. Global solar radiation (SPUR2), Salto, 1981 to 1990

model to other soils or regions of the country is attempted. In spite of the problems encountered, fairly good results can be expected from the application of this model under Uruguayan conditions.

\section{LITERATURE CITED}

Berretta EJ (1994) Producción de pasturas naturales en el Basalto. In: Pasturas y producción animal en áreas de ganadería extensiva. Serie Técnica 13, Instituto Nacional de Investigación Agropecuaria (INIA), Montevideo
Boshell JF, Chiara JP (1982) Regionalización agroclimática de la República Oriental del Uruguay. Nota Técnica 50, Publicación No. 36, Dirección Nacional de Meteorología, Montevideo

Carámbula M (1991) Aspectos relevantes para la producción forrajera. In: Serie Técnica 19. Instituto Nacional de Investigación Agropecuaria (INIA), Montevideo

Crempien C (1983) Antecedentes técnicos y metodología básica para utilizar en presupuestación en establecimientos ganaderos. Editorial Hemisferio Sur, Buenos Aires

De Souza PJ (1985) Producción y calidad de las pasturas naturales del Uruguay. In: Resumenes del Primer Seminario Nacional sobre Campo Natural, Cerro Largo Facultad de Agronomía, Montevideo

Gonnet M (1981) Utilización del balance hídrico del suelo para estimar días aptos de laboreo en La Estanzuela. Investi Agron 2(1)

Meirelles M, Riani J (1988) Producción de forraje según tres frecuencias de corte en suelos de diferente profundidad desarrollados sobre Basalto (Parte I). Tesis de grado. Facultad de Agronomía, Universidad de la República, Montevideo

Rosengurtt B (1979) Tablas de comportamiento de las especies de plantas de campos naturales en el Uruguay. División de Publicaciones y Ediciones de la Universidad de la República, Montevideo

U.S. Country Studies Program (1994) Guidance for vulnerability and adaptation assessments, Version 1.0. U.S. Country Studies Management Team, Washington, DC

Wight JR, Skiles JW (eds) (1987) SPUR: Simulation of Production and Utilization of Rangelands. Documentation and user guide. ARS 63, U.S. Department of Agriculture, Agricultural Research Service, Boise, ID

Zunino R, Baptista I (1988) Producción de forraje según tres frecuencias de corte en suelos de diferente profundidad desarrollados sobre basalto (Parte II). Tesis de grado, Facultad de Agronomía, Universidad de la República, Montevideo 